\title{
Stimulating pre-service teacher academic achievement through problem- based learning (PBL)
}

\author{
Mohd Nazir Md. Zabit ${ }^{1, *}$, Eleni Karagiannidou ${ }^{2}$, Tirzah Zubeidah Zachariah ${ }^{3}$ \\ ${ }^{1}$ Faculty od Education and Human Development, Sultan Idris Education University, Tanjung Malim, Malaysia \\ ${ }^{2}$ HASS School of Education, University of Strathclyde, Glasgow, Scotland, United Kingdom \\ ${ }^{3}$ Faculty of Education and Social Scfiences, Universiti Selangor (UNISEL), Selangor, Malaysia
}

\section{A R T I C L E IN F O}

\section{Article history:}

Received 27 August 2016

Received in revised form

27 October 2016

Accepted 2 November 2016

Keywords:

Problem-based learning

Academic achievement

Business education

\begin{abstract}
A B S T R A C T
This study is focused on Problem-Based Learning (PBL) methodology and academic achievement due to the fact that academic achievement is a core learning process which also involves a problem solving task. A quasiexperimental design was employed in this study, where 45 pre-service teachers undertaking a B. Ed (Economics) were randomly assigned to the experimental $(n=23)$ and control groups $(n=22)$. The PBL method was utilised in the experimental group while the traditional learning method was utilised in the control group. The analysis focused on comparisons between the PBL and traditional learning groups in terms of their Academic Achievement Test (AAT), a series of one-way between group analysis of covariance (ANCOVA) tests, in which pre-AAT was used as a covariate when looking at differences between the PBL and TL groups in mid- and post-AAT. Regarding the effects of PBL on pres-service teachers' academic achievement as measured by an instrument, the AAT showed at baseline no differences existed between the two groups. The PBL method yielded significantly higher Achievement scores at mid-intervention and post-intervention test, which indicated better students' academic achievement. The study findings showed the positive effects of PBL towards pre-service teachers' performance in academic on Business Education in Malaysia.
\end{abstract}

(C) 2016 The Authors. Published by IASE. This is an open access article under the CC BY-NC-ND license (http://creativecommons.org/licenses/by-nc-nd/4.0/).

\section{Introduction}

Problem-Based Learning (PBL) refers to the learning that occurs from the process of working towards the understanding or resolution of a problem (Barrows and Tamblyn, 1980). In the conventional way, Business Education programs normally use the one tier teaching method which include the teacher-centred approaches such as lectures and tutorials. In these situations, instructors give lectures to disseminate knowledge and by the end of a study session or semester, an assessment is made of student performance, which is mainly based on examination. This step is regarded as important whereby students recall what they already know about a topic (Barrows and Tamblyn. 1980) in order that the teachers then provide them a context for

\footnotetext{
* Corresponding Author.

Email Address: mohd.nazir@fppm.edu.my (M. N. Md. Zabit)

https://doi.org/10.21833/ijaas.2016.11.006

2313-626X/@ 2016 The Authors. Published by IASE.

This is an open access article under the CC BY-NC-ND license

(http://creativecommons.org/licenses/by-nc-nd/4.0/)
}

learning (Norman and Schmidt, 1992; Schmidt, 1983).

Currently, the Business Education (including economics education for pre-service teacher) system in Malaysia has seen some variations in terms of performance assessment; however, these have usually been limited to case studies, report submissions and presentations which are not much different from a teacher-centred approach (Md. Zabit, 2013). A few possibilities for strengthening the process of teaching and learning in higher education may involve taking advantage of educational technologies and the promotion of more studentcentered learning, as these could help in producing more functional graduates. This is related to the Ministry of Higher Education's (MOHE) target of increasing the percentage of graduates in relevant employment six months after graduating from $74.1 \%$ to $78 \%$. The Malaysian universities would need to focus on strengthening student-centred learning approaches such as: Outcome Based Education (OBE), PBL, Modular Approach and Case Studies in order to transform the students into outstanding individuals. In our understanding, to remain competitive in these times of changing 
educational needs, Malaysia must generate high value-added capabilities of higher education graduates. Therefore, education institutions must produce confident students who can act to solve a problem, and then make a good decision.

\subsection{Teaching business education in Malaysia}

The quality of Malaysian higher education among the graduates of Business Education could be summed up from the critical feedback given by a well-known historian and local academician, Emeritus Professor Dr. Khoo Kay Khim. He viewed the current education system as causing significant problems in assessing the quality of graduates. Furthermore, he argued that lecturers and educators should not inform the students or provide tips on what would come out in the examination or how to answer questions; students should have to analyse the problems for themselves.

As stated by $\mathrm{Ng}$ (2008), similar concerns have driven educational reforms in nations around the globe. An example is when Singapore prepared to overhaul its assessment system. As noted by the Education Minister, Tharman Shanmugaratnam:

We need less dependence on rote learning, repetitive tests and a 'one size fits all' type of instruction, and more on engaged learning, discovery through experiences, differentiated teaching, the learning of life-long skills, and the building of character, so that students can... develop the attributes, mindsets, character and values for future success (Ng, 2008).

In general, PBL has been found to have positive values which are effective in teaching and learning process, and provide an alternative to the traditional methods of teaching and learning. Previous studies have indicated that through PBL, students are able to maintain information and ideas in the classroom for a longer time and without prejudice regarding issues of syllabus content or subject. These studies also reveal that performance on achievement tests is either similar, if not better than the achievement where non-PBL approaches where used. This proves that PBL is geared towards becoming one of the best alternatives to the traditional pedagogy.

\subsection{PBL and academic achievement}

PBL has existed as a methodology long before it was introduced as formal classroom concept (Boud and Feletti, 1991). Its origin can be traced to the progressive movement, especially to Dewey's (1944) belief that teachers should teach by appealing to the students' natural instincts to investigate and create. This learning approach had spread to medical schools in North America, Europe, and Australia in the early 1980's and has since been adopted by schools of engineering, architecture, social work, law, and nursing among others (Boud and Feletti, 1997).

The McMaster University model (Barrows and Tamblyn, 1980) shows that the PBL method involves three phases: revealing problem scenarios; finding information; and discussing and applying new knowledge to the problems. Many studies have supported the effectiveness of the PBL approach on students' academic achievement (Major and Palmer, 2012; Neo and Neo, 2001; Ward and Lee, 2002; Kivela and Kivela, 2005; Yuan et al., 2008). However, these studies are mainly in the field of science and technology, especially in the fields of medicine, nursing, the sciences, hospitality and engineering.

Currently, this study seeks to occupy a research space by applying PBL to critical thinking (CT) in Business Education. Tan and Ng (2006) stated that PBL is useful for its emphasis of active learning through solving 'real-world' problems as well as its multi solution approach; it is likely to have an advantage if positioned as a pedagogical strategy for entrepreneurship education. Yuan et al. (2008) stated that PBL approach, in the context of nursing education, actually increased students CT skill more than the lecture approach. They also examined the effect of PBL on nursing students' CT skills. They found that PBL students' CT skills did not appear to show significant great development in relation to the deduction, inference and evaluation sub-scale scores. This argument does not stand up, as for many students, the types of active learning like PBL requires is and an unusual experience. A particular method for assisting students in their learning understanding of the PBL process is to ask them to reflect on the experience of PBL at key points in the process (Major and Palmer, 2001). This method allows students to analyze and find the solution to a problem, rather than simply applying methods that are already known. Learning begins with a problem to be solved, and the problem is posed in such a way that learners need to gain new knowledge before they can solve the problem.

Additionally, PBL helped to promote deep approaches of learning instead of surface approach (Dochy et al., 2003; Biggs, 2003). As stated by Kivela and Kivela (2005) and Du (2006), after exposure to PBL methods, students showed that they were able to take a more pro-active role in their learning; they more readily developed self-management skills in term of their own learning (Maddocks, 2004) and more self-directed in their learning activities. Likewise, the students talked about learning in PBL as being both fun and hard at the same time (Salleh et al., 2007). An example for this is group activities rated the highest out of the classroom activities that the students participated in. Qualitative feedback from the students also showed that they valued communicative and interactive learning activities more than the traditional method of learning via lectures (Kivela and Kivela, 2005).

In Savin-Baden's view (2003), PBL helped to develop criticality of learners and the students may be better able to integrate basic science knowledge into the solutions. A recent development in tertiary education involves the application of PBL as a curricular vehicle to develop student talent. As stated by Brownell and Jameson (2004), PBL has 
been used for a decade in a graduate management program. It is an approach which capitalizes on synergies among cognitive, affective and behavioural learning. While Business Education usually privileges cognitive learning, affective learning is equally important. Perhaps it is true that by focusing on real-world problems, PBL helps students to appreciate multiple perspectives, recognize nonrational elements of decision making, and confront ethical quandaries. This shows us that PBL is an effective method to encourage students to analyze and think critically. It is hoped that by thinking critically, the students would not simply imitate existing Business Education methods, but would create and pioneer new approaches.

The types of problems and how these problems should be solved can influence students' thinking and how they gain knowledge. Specifically, the problem and problem solving process are the main characteristics in PBL. Boud and Feletti (1997) stated that the advantage of PBL is to help Business Education students to develop the ability for selfdirected learning (SDL) which would enable them to cope with the ever -changing and increasing body of knowledge they need to succeed as professionals

\section{The present study}

\subsection{Aims}

This research focuses on the utilisation of PBL methods among lecturers to stimulate pre-service teachers' academic achievement using PBL methodology.

\subsection{Research question}

i. Does PBL influence pre-service teachers' academic achievement in Business Education?

\subsection{Setting and participants}

The intervention part of this study was administered at the Faculty of Business and Economics, Sultan Idris Education University, Malaysia. The convenience sample was made up of a group of B. Ed (Economics) final semester students (pre-service teachers). They were randomly assigned into two different groups: the experimental group utilising PBL $(n=23)$ and the control group, TL, which used the traditional method $(n=22)$.

\subsection{Data collection, instruments and procedures}

The instrument used to measure the pre-service teachers' performance in PEA3063 - Population Economics and Policy before and after the end of the experimental period [(week 7) - mid-semester examination and one week after end of intervention (week 15) - final semester examination] was based on the knowledge which they have gained during the experiment. The pre-test questions were 40 multiple-choice questions covering the Fundamental of Economic (Microeconomics and Macroeconomics) topic learnt by the respondents in the previous semesters. The subject lecturer had specifically developed the Fundamental of Economics test for this study. The main purpose of administering this pre-test was to investigate the students' prior knowledge in basic of Economics for both groups before the intervention.

For the mid-intervention test, the questions were in the form of a short essay and structured questions, such as listing, ranking, scaling etc. In general, the questions form part of the mid-semester examination which included five topics of the subject syllabus (half of the syllabus - starting from week 2 until week 6).

The final semester test questions were designed by the subject lecturer with the help of an expert on Population Economics and Policy for the validity of the test content. The mean scores were used to compare the performance of the PBL group and the TL group. The Achievement Test was developed with the help of subject lecturer. The format of the test followed the criteria reference test based on the Bloom's Taxonomy (low cognitive or high cognitive). In the process of designing this final test, the subject lecturer had referred to various sources like the PEA 3063 - Population Economics and Policy syllabus, main book reference, additional book reference, Internet and previous semester test. The test specifications table had been constructed based on $40 \%$ on knowledge level and comprehension. Another $60 \%$ was based on the application, analysis and synthesis of thinking skills. The instrument contained 40 multiple choice items, 10 structure questions and 3 essay questions.

\subsection{Data analysis}

For the purpose of answering the Research Question; Does PBL influence pre-service teachers' academic achievement in Business Education?, an independent-sample $t$ test was conducted to compare the two groups' academic achievement at pre-test, mid-intervention test and post-test. A further analysis was conducted to support the results from an independent-sample $t$ test. It was decided that the researcher would conduct a series of one-way between groups analysis of covariance (ANCOVA) tests, whereby pre-AAT was used as a covariate when looking at differences between the PBL and TL groups in mid- and post-AAT. In order to test this, SPSS was utilised to treat the scores on the prior-test as a covariate to control for pre-existing differences between the groups. Preliminary checks were conducted to ensure that there was no violation of the assumptions of normality, linearity, homogeneity of variances, and reliable measurement of the covariate.

\section{Results and discussion}




\subsection{The effectiveness of PBL toward students' academic achievement}

Table 1 shows no significant difference between the PBL and the TL groups regarding the students' AAT at pre-test. The PBL students' scored significantly higher in the mid-intervention test $(\mathrm{M}=74.30, S D=4.17)$ compared to $\mathrm{TL}$ group $(\mathrm{M}=68.50, \quad S D=3.34)$. Likewise, in the post-test
$(\mathrm{M}=78.97, \quad S D=5.80)$ compared to $(\mathrm{M}=71.05$, $S D=3.11$ ), $[t=5.66, d f=43, p=0.001$ (two-tailed)]. These results conclude that, while at baseline (before intervention), no difference existed between the two groups, at mid-intervention and final intervention the PBL method was associated with significantly higher Achievement scores, therefore, better students' academic achievement.

Table 1: Students' academic achievement (mean and $S D$ ) at pre-test, mid-intervention test and post-test

\begin{tabular}{|c|c|c|c|c|c|c|}
\hline $\mathrm{AAT}^{*}$ & $\begin{array}{c}\text { PBL } \\
(\mathrm{n}=23) \\
\text { Mean (SD) }\end{array}$ & $\begin{array}{l}\text { TL }(\mathrm{n}=22) \\
\text { Mean (SD) }\end{array}$ & Mean diff & t-value (df) & Sig. (2 tailed) & Sig \\
\hline Pre-test & $74.65(2.17)$ & $74.40(5.94)$ & 0.243 & $0.184(43)$ & 0.855 & n.s \\
\hline Mid-Inter & $74.30(4.17)$ & $68.50(3.34)$ & 5.804 & $5.133(43)$ & 0.001 & Sig. \\
\hline Post-test & $78.97(5.80)$ & $71.05(3.11)$ & 7.91 & $5.66(43)$ & 0.001 & Sig. \\
\hline
\end{tabular}

Note: Each type of AAT is different in term of contents, difficulties index, weighted average and therefore scores on the tests conducted at the different time points are not directly comparable.

A one-way between groups analysis of covariance (ANCOVA) was conducted to compare the effectiveness of two different groups of interventions on their academic achievement at mid-intervention test and post-test. The scores in the pre-test were treated as a covariate. The use of well-chosen pretest covariates can be utilised to help the researcher reduce the confounding influence of group differences. The independent variable was the type of intervention or intervention group (PBL and TL). The dependent variable consisted of scores on the mid- and post-intervention tests on AAT, with the respective AAT pre-test used as the covariate in this analysis.

The analysis from Levene's test showed a Sig. value of .21, which was much larger than the cut-off value of .05. After adjusting for prior-test scores, there were significant differences between the two groups (PBL and TL) on mid-intervention AAT test $\left(F_{(1,43)}=30.93, p=.001\right.$, partial eta square=.424. $)$. Looking at the mean and $S D$ for mid ATT from this analysis, PBL $(74.3, S D=4.17)$ scored slightly higher than the TL group $(M=68.5, S D=3.35)$, even after controlling for pre-AAT.

After adjusting for prior-test AAT scores, there were significant differences in AAT between the PBL and TL groups) on post-test scores $\left(F_{(1,43)}=43.73, p\right.$ $=.001$, partial eta square $=.51$ ). The mean and $S D$ for post-ATT in this analysis showed that PBL (79, $S D=5.8$ ) scored slightly higher than the TL group $(\mathrm{M}=71.1, S D=3.1)$, even after controlling for pre-AAT. These results indicate that even after controlling for any potential differences in academic achievement before the intervention, there were still differences at mid-and post-tests between the two groups, PBL versus TL.

As indicated in the data analysis, the students in PBL group showed higher achievement compared to the TL group in the AAT. It seems that the students in PBL group were able to make use of the subject contents learned and the information search activity also increased their understanding of the concepts learned. This is in line with the findings of previous studies where it was found that the PBL method was able to produce positive results for the courses, including Economics subjects (Gabr and Mohamed, 2011; Kimberly et al., 2006; Martin et al., 2008; Sahin, 2010). However, the students in the TL group showed the opposite performance. At the pre-test stage, the achievement of two groups was almost the same. Wile there was an improvement in the PBL group achievement, the TL group did not show an overall improvement. It is possible that students in the TL group (still bound by the rote-learning) were less likely to apply teaching and learning, and were more involved in high-level thinking such as analysis, problem solving and descriptive, specifically for the end of the study subjects such as PEA3063 - Population Economics and Policy course. The increase in PBL pre-services teachers' performance in this study supports the research assumptions;

a. To solve the population economics and policy problem, the pre-services teachers must use declarative knowledge of the subject in an analytic and creative manner. This will increase the preservices teachers' understanding towards the learning topics or subject.

b. The pre-services teachers' were actively involved in problem-solving process, where the knowledge was always applied to new situations. The more involved the students were in the problem solving process, the more often they had to think about the topics or subject. It is expected that this process also increases students' understanding of the topics or subject.

\section{Conclusion}

The findings indicate that the pre-service teachers took the opportunity through a PBL approach to improve their academic achievement, develop inter-personal and intra-personal communication skills, and learn how to deliver their own opinions and judgements effectively. All these are important characteristics for life in the modern world. As such, the research and the results of this study may act as a point of reference and guideline 
for the implementation and the effectiveness of the PBL approach in related studies on students' academic achievement in Business Education programs.

\section{Acknowledgment}

The authors would like to express utmost appreciations to the Research Management and Innovation Center (RMIC), Sultan Idris Education University and Ministry of Higher Education (MOHE) for the allocation of the Fundamental Research Grant Scheme.

\section{References}

Barrows HS and Tamblyn RM (1980). Problem-based learning: An approach to medical education. Springer Publishing Company. Problem-based learning: An approach to medical education. Springer, New York, USA.

Biggs J (2003). Teaching for quality learning at university. Open University Press, Berkshire, UK.

Boud D and Feletti GI (1991). The challenge of problem-based learning. Kogan Page, London, UK.

Boud D and Feletti GI (1997). The challenge of problem-based learning. $2^{\text {nd }}$ Edition, Kogan Page, London, UK.

Brownell J and Jameson DA (2004). Problem-based learning in graduate management education: An integrative model and interdisciplinary application. Journal of Management Education, 28(5): 558-577.

Dewey J (1944). Democracy and education: An introduction to the philosophy of education. The Free Press, New York, USA.

Dochy F, Segers M, Van den Bossche P and Gijbels D (2003). Effects of problem-based learning: A meta-analysis. Learning and Instruction, 13(5): 533-568.

Du XY (2006). Gendered practices of constructing an engineering identity in a problem-based learning environment. European Journal of Engineering Education, 31(1): 35-42.

Gabr H and Mohamed N (2011). Effect of problembased learning on undergraduate nursing students enrolled in nursing administration course. International Journal of Academic Research, 3(1): 154-162.

Kimberly H, Michael H, Robert BJr, Linda H and Gina J (2006). Problem-based learning outcomes: Ten years of experience at the University of Missouri-Columbia School of Medicine. Academic Medicine, 81(7): 617-625.

Kivela J,and Kivela RJ (2005). Student perceptions of an embedded problem-based learning instructional approach in a hospitality undergraduate programme. International Journal of Hospitality Management, 24(3): 437-464.

Maddocks A (2004). Personal development planning and portfolio building-introducing undergraduates to the processes of professional development. In: Caroline B and Moore I Effective (Eds.), Learning and Teaching in Engineering: 171-184, Routledge, London.

Major CH and Palmer B (2001). Assessing the effectiveness of problem-based learning in higher education: Lessons from the literature. Academic Exchange Quarterly, 5(1): 4-9.

Martin L, West J and Bill K (2008). Incorporating problem-based learning strategies to develop learner autonomy and employability skills in sports science undergraduates. Journal of Hospitality, Leisure, Sports and Tourism Education (Pre-2012), 7(1): 18-30.

Md. Zabit MN (2013). The implementation and impact of problem-based learning on students' critical thinking skills in teaching business education in Malaysia. Ph.D. Dissertation, HASS School of Education, University of Strathclyde, UK.

Neo KT and Neo M (2001). A constructivist learning experience: Reconstructing a web site using web based multimedia authoring tools. Australian Journal of Educational Technology, 17(3): 330350.

Ng PT (2008). Educational reform in Singapore: From quantity to quality. Educational Research for Policy and Practice, 7(1): 5-15.

Norman GR and Schmidt HG (1992). The psychological basis of problem-based learning: A review of the evidence. Academic Medicine, 67(9): 557-565.

Sahin M (2010). Effects of problem-based learning on university students' epistemological beliefs about physics and physics learning and conceptual understanding of Newtonian mechanics. Journal of Science Education and Technology, 19(3): 266-275.

Salleh BM, Othman H, Esa A, Sulaiman A and Othman $H$ (2007). Adopting problem-based learning in the teaching of engineering undergraduates: A Malaysian experience. In the International Conference on Engineering Education, Coimbra, Portugal: 3-7.

Savin-Baden M (2003). Facilitating PBL: Illuminating perspectives. The Society for Research into Higher Education and Open University Press, London, UK.

Schmidt HG (1983). Problem-based learning: Rationale and description. Medical Education, 17(1): 11-16. 
Tan SS and Ng CF (2006). A problem-based learning approach to entrepreneurship education. Education+ Training, 48(6): 416-428.

Ward JD and Lee CL (2002). A Review of Problembased Learning. Journal of Family and Consumer Sciences Education, 20(1): 16-26.
Yuan H, Kunaviktikul W, Klunklin A and Williams BA (2008). Improvement of nursing students' critical thinking skills through problem-based learning in the People's Republic of China: A quasiexperimental study. Nursing and Health Sciences, 10(1): 70-76. 